\title{
Civilisations
}

Revue internationale d'anthropologie et de sciences

humaines

49 | 2002

Pain, fours et foyers des temps passés

\section{Pre - and protohistoric bread in Sweden : a definition and a review}

\section{Ann-Marie Hansson}

\section{(2) OpenEdition \\ Journals}

Édition électronique

URL : http://journals.openedition.org/civilisations/1432

DOI : 10.4000/civilisations. 1432

ISSN : 2032-0442

\section{Éditeur}

Institut de sociologie de l'Université Libre de Bruxelles

\section{Édition imprimée}

Date de publication : 3 juin 2002

Pagination : 183-190

ISBN : 0009-8140

ISSN : 0009-8140

Référence électronique

Ann-Marie Hansson, «Pre - and protohistoric bread in Sweden : a definition and a review », Civilisations [En ligne], 49 | 2002, mis en ligne le 01 juin 2005, consulté le 30 avril 2019. URL : http:// journals.openedition.org/civilisations/1432 ; DOI : 10.4000/civilisations.1432

Ce document a été généré automatiquement le 30 avril 2019

(c) Tous droits réservés 


\title{
Pre - and protohistoric bread in Sweden : a definition and a review
}

\author{
Ann-Marie Hansson
}

Many thanks to Kai Fechner for inviting me to participate both in the 1995 « Bread, Hearths and Ovens " workshop and in the subsequent publication. Warm thanks to Uaininn O'Meadhra for kindly checking my English and also to Kjell Persson for creating the map-illustration.

\section{Introduction: The age and distribution of archaeological bread remains in Sweden}

1 Cereals have been cultivated in Sweden since the Stone Age, i.e. since c. 4000 BC. But with the exception of «blood-porridge » (Arrhenius 1984; Arrhenius \& Lidén 1988), we can only guess at the form in which cereals were eaten at that time. However, in the later archaeological material we can discern traces of a tradition to combine flour and grain with different animal products to create various dishes, especially grain-pastes which were sometimes leavened. At the same time bread - i.e. grain in prepared form - was also consumed. The majority of surviving Swedish prehistoric bread can be dated to the later part of the Early Medieval Period (which in Sweden incorporates the Migration Period (400 -550 AD), the Vendel Period (550 -800 AD) and the Viking Age (800 -1050 AD).

2 A concentration of findings can be noted in eastern central Sweden, while the northernmost find comes from Västbyn, in Frösön in the province of Jämtland. This was analysed by Prof. em. Hakon Hjelmqvist, Lund, who suggested that blood may have been one of the ingredients in the dough, together with hulled barley (Hjelmqvist $1990: 17$ ).

3 About 150 charred prehistoric loaves of bread are now known from archaeological excavations. 


\section{The main sites of discovery}

\subsection{Birka}

4 The largest concentration, over 64 loaves, of which 33 have been analysed (Hjelmqvist 1984), were found in cremation graves at the cemeteries in Birka - the first prototown in Sweden, situated on the island of Björkö in Lake Mälaren c. $30 \mathrm{~km}$ west of Stockholm and dated c. 750-975 AD (Fig. 1). Here c. 1000 graves were excavated during the end of the 19 th century. Of these, c. 500 proved to hold cremation burials, and c. $10 \%$ of the cremation graves contained bread loaves. Bread loaves were also found in graves on the island of Björkö outside the prototown of Birka. These graves probably belonged to independent farms contemporary with Birka (Hansson 1997).

\subsection{Ljunga and Boberget on Östergötland}

Among the earliest findings of prehistoric bread mention should also be made of those found during the excavations of the cremation graves at Ljunga in the province of Östergötland at the beginning of this century (Schnittger 1912; Rosendahl 1912), and during the excavations of the fortified farm of Boberget in the province of Östergötland (Schnittger 1912). These loaves were microscopically analysed soon after discovery, constituting the earliest analyses of bread material in Sweden (Rosendahl 1909; Hjelmqvist 1990).

\subsection{Helgö}

6 Approximately 30 bread loaves (20 of which were analysed) were found during the excavations of the migration-viking period farms at Helgö (Holmqvist 1963) (Fig. 1). Like Birka, Helgö is situated on an island in Lake Mälaren, which during this period formed a gulf of the Baltic Sea. Thus there is a remarkable concentration of finds of bread in the Mälar area. The Helgö loaves were found in a longhouse and in a sunken-floor hut. This bread had a somewhat older dating than the loaves from the prototown of Birka (Viklund 1998).

\subsection{Different sites in central Sweden}

7 A further 30 bread loaves have been analysed and published, originating from different sites in central Sweden (Hjelmqvist 1990). In addition there are a number of loaves awaiting publication. Far more loaves than have been recognized were originally deposited as gravegifts. This is especially clear from the re-examination of material from older excavations of cremation graves, which have yielded additional bread finds, as for instance at Birka and in the important chieftain site of earlier date at Vendel, also in eastern central Sweden. 


\section{Conditions in which bread is preserved}

$$
\text { The }
$$
turned out to be very special : whole seeds of gold-of-pleasure (Camelina sativa) and flax (Linum usitatissimum) were clearly evident. The seeds of these species have a high fat content, which here resulted in the seeds sticking together into a "cake » when accidentally heated. This organic material was probably never baked (Hanson et al. 1993). There are also further organic materials which resemble bread, but do not constitute
bread. One example is a bread-like find from a migration period ringfort on öland, one of

\section{A definition of prehistoric bread and other cereal - based dishes}

11 The need to distinguish between bread and other cereal -based dishes on the one hand and other types of organic material on the other hand, demands a definition of prehistoric bread, which can be stated basically as follows :

Ingredients : consisting mainly of ground food plants, usually cereals, with the addition of a liquid and sometimes a leavening substance.

13 Preparation: working -up into a dough, followed by baking in an oven or oven -like construction, or roasting at or on an open fire, on embers or in ashes (Hansson 1994 :8).

This definition allows plant species other than cereals to be ground into the baking flour, in contrast to later Medieval bread. Most important to remember when distinguishing between bread and for instance porridge and grain -paste, is that bread is baked and the ingredients are ground.

\section{Ingredients and preparation}

Microscopic analyses of Swedish prehistoric bread loaves have shown that not only flour from cereals was used, but also flour from peas, vetches, flax, gold of pleasure and fieldweeds. Most of the loaves were baked from finely sieved flour and have not been leavened. Traces of bark of Scots pine have also been found (Hansson 1995a, b). Most notably, one loaf found in a cremation grave at Ljunga was long thought to be bark-bread. 
Now, however, it is considered that the cells from Scots pine, both bark and wood, are merely a contamination either from the hearth at baking, or from the funeral pyre.

\section{Morphology and size}

In Birka, in those cases where it was possible to make a secure classification based on the morphology, we observed a predominance of circular bread with a diameter of less than $5 \mathrm{~cm}$ and a thickness of c. $0,5 \mathrm{~cm}$ ( 25 cases in total). With regard to such small dimensions perhaps the term «bun» or « miniature bread » is more accurate than merely «bread». There are however also other forms, for instance, an oval shape, an indented «cloverleaf " shape, and one small curved piece of bread which was earlier interpreted as a figure -of -eight, but now seems more possibly ring-formed. Rare examples occur of larger loaves, up to a diameter of $17-18 \mathrm{~cm}$. A loaf from the fortified farm of Boberget was semi-spherical, the only early medieval Swedish loaf with this form. Characteristic for grave-bread found in the cemeteries at Birka is that many of them, even the small loaves, had been furnished with metal -strings for suspension.

\section{What determined the deposition of bread in a grave?}

17 At Birka, cremation funerals were carried out by all social groups. An analysis of these cremation graves shows that $42 \%$ of the graves with bread deposits contained rich gravegifts. Of the total number of cremation graves in Birka, only $20 \%$ contained grave-gifts indicative of wealth. The conclusion must be that this higher -than -average proportion of rich « bread graves » indicates that « bread graves » could mark rich burials. Both men and women, and in one case a child, received bread loaves as funeral deposits. Sex and age seem to be of no importance for the choice of bread as a grave-gift (Hansson 1997).

That bread, as a cereal -based product, was of symbolic importance is indicated by the metal -strings found in many examples, or by the traces of rust, where the iron-string had disappeared. Why should metal be used for this function? Metal was an expensive material during the Early Medieval Period in the Nordic countries. It would have been more natural to use, for instance, a plant material like bast, an osier, or a string of flax or hemp. Furthermore, loaves were often placed within the grave urn or just beside it, the most important location in the grave. Bread deposits often coincide in the Birka graves with Thor's hammer rings also made of iron, sometimes with metal pendants. These are usually associated with ideas of fertility and resurrection. Prehistoric bread probably had a similar symbolic function following a very widely established tradition (Eliade 1958; Camporesi 1993).

Bread was consumed in many parts of the prehistoric /early medieval world (Währen 1963,1967,1978 ; Fechner 1992, 1996 ; Samuel 1994). Turning to the future, let us hope for continued bread findings and with them the possibility to perform an increasing variety of analyses which will enable us to better interprete the important role of bread, both as an everyday food and as a vital symbol-bearer within society. 
Fig. 1 : Map showing the locality of Sweden's two most lucrative sites of ancient bread : Birka and Helgö, situated on islands in Lake Mälaren, east central Sweden. CAD drawing Kjell Persson, ARL, Stockholm University.

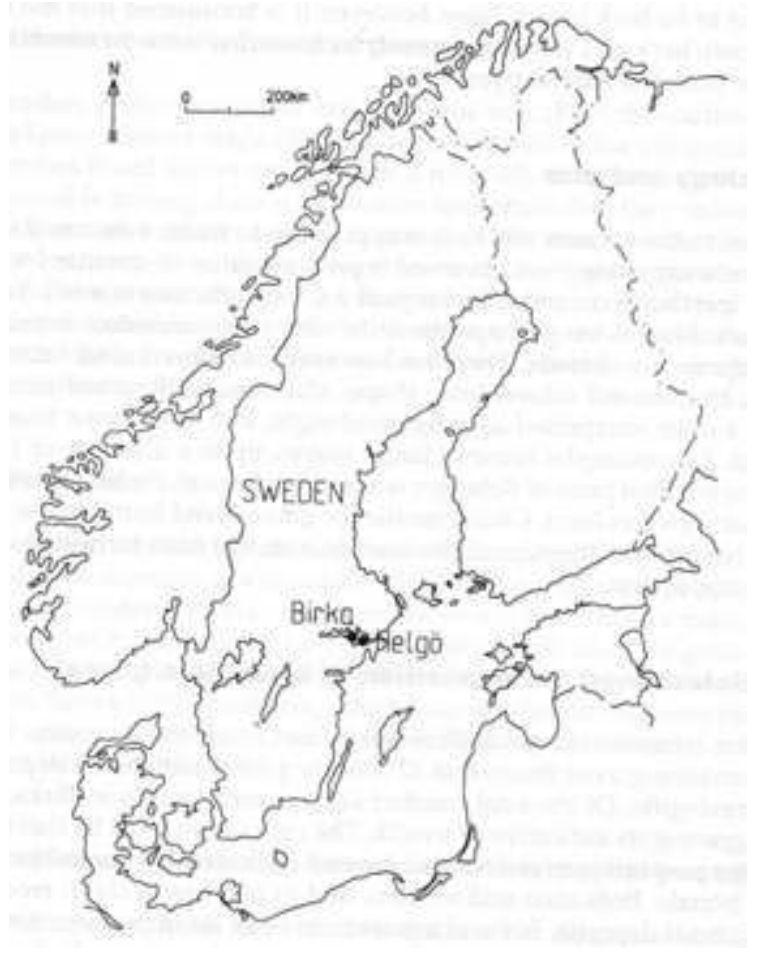

\section{BIBLIOGRAPHIE}

ARRHENIUS, B., 1984. Analysrapporter gällande organiskt material på keramikskärvor funna i Löddesborg, Löddeköpinge sn, Skåne, in JENNBERT, K., Den produktiva gåvan. Acta Archaeologica Lundensia. Series in 4o Nr 16, pp. 174-181.

ARRHENIUS, B. \& LIDÉN, K., 1988. Fisksoppa eller vegetabilisk gröt ? Diskussion kring matresterna från Tybrind Vig. Laborativ Arkeologi 3. Arkeologiska Forskningslaboratoriet, Stockholms Universitet, pp. 7-15.

CAMPORESI, P., 1993. The Magic Harvest. Food, Folklore and Society. Cambridge.

ELIADE, M., 1958. Patterns in Comparative Religion. London and New York.

FECHNER, K.,1992. Le pain avant l'histoire : un bilan archéologique et palethnologique pour le nord-Oest de l'Europe. Du grain au pain. Symboles, savoirs, pratiques (ed. M. MESNIL). Collection Ethnologies d'Europe $\mathrm{n}^{\circ} 2$. Les correspondances de Civilisations. Institut de Sociologie de l'Université Libre de Bruxelles, pp. 43-81.

FECHNER, K., 1996. El pa abans de la historia : estat arqueologic i paleoetnologic de la questio a l'oest d'Europa. Cota Zero 12, pp. 61-75. 
HANSSON, A.-M., 1994. Grain-paste, Porridge and Bread. Ancient cereal-based food. Laborativ Arkeologi 7. Journal of Nordic Archaeological Science. Stockholm, pp. 5-20.

HANSSON, A.-M., 1995a. The Ljunga Bread - Prehistoric Bark Bread ? Inner bark as a nutritive substance in the light of comparative evidence from written records. Landscapes and Life. Studies in honour of Urve Miller. PACT 50. Rixensart, pp. 385-398.

HANSSON, A.-M., 1995b. The Bread from Ljunga in Central Sweden - New analyses. Laborativ Arkeologi 8. Journal of Nordic Archaeological Science. Stockholm, pp. 38-49.

HANSSON, A.-M., 1997. On plant food in the Scandinavian peninsula in Early Medieval Times. The Archaeological Research Laboratory, Stockholm University. Thesis and Papers in Archaeology B :5 (diss.).

HANSSON, A.-M., LIDÉN, K. \& ISAKSSON, S., 1993. The charred seed-cake from Eketorp. Sources and Resources. Studies in Honour of Birgit Arrhenius. PACT 38. Rixensart, pp. 302-315.

HJELMQVIST, H., 1984. Botanische Analyse einiger Brote. Arwidsson, G. (ed.), Birka II :1. Systematische Analysen der Gräberfunde. Stockholm, pp. 261-272.

HJELMQVIST, H., 1990. Über die Zusammensetzung einiger prähistorischer Brote. Fornvännen 85, pp. 9-21.

HJELMQVIST, H., 1963. Forntida bröd och bakugnar från Helgö. Information från Brödinstitutet, årg. 6 nr 5. Stockholm, pp. 3-8.

ROSENDAHL, H.V., 1909. Mikroskopisk analys af brödfynd från 400-500-talet. Svensk Botanisk Tidskrift 3 :1. Stockholm, pp. 41-46 (with a German summary).

ROSENDAHL, H.V., 1912. Mikroskopisk undersökning af vegetabiliskt fornfynd. Svensk Farmaceutisk Tidskrift No 1, pp. 1-3.

SAMUEL, D., 1994. An archaeological Study of Baking and Bread in New Kingdom Egypt. Darwin College, University of Cambridge (diss.).

SCHNITTGER, B., 1912. Några förhistoriska brödfynd. Fornvännen, pp. 1-6.

VIKLUND, K., 1998. Cereals, Weeds and Crop Processing in Iron Age Sweden. Methodological and interpretive aspects of archaeobotanical evidence. Archaeology and Environment 14. Umeå, (diss.).

WÄHREN, M., 1963. Brot und Gebäck im Leben und Glauben der Alten Ägypt. Bern

WÄHREN, M., 1967. Brot und Gebäck im Leben und Glauben des Alten Orient. Bern

WÄHREN, M., 1978. Brot. Reallexikon der germanischen Altertumskunde 3. Berlin

\section{RÉSUMÉS}

Cet article présente brièvement les différentes découvertes archéologiques de pain, de galettes et d'autres aliments céréaliers faites en Suède. Il insiste sur l'importance de définitions claires et sur l'influence des conditions de préservation. Mis à part la différenciation sur base de la morphologie et la taille, l'application de nombreuses analyses a permis une différenciation basée sur les ingrédients et le mode de préparation. Enfin, la distribution des pains dans le cimetière de Birka est discutée et interprétée.

This article presents shortly the different archaeological discoveries of breads, buns and other cereal dishes found in Sweden. It insists on the importance of clear definitions and on the 
influence of preservation conditions. Besides a differentiation based on size and morphology, a certain number of analytical results allow for a differentiation based on ingredients and preparation. The interpretation of the distribution of breads in the cemetery of Birka is discussed.

INDEX

Mots-clés : Pain, céréales, artefact archéologique, Suède

Keywords : Bread, cereals, archaeological artefact, Sweden

\section{AUTEUR}

ANN-MARIE HANSSON

Arkeologiska Forskningslaboratoriet (AFL), Stockholm Universitet, Sverige 